EPiC Series in Language and Linguistics
Volume 2, 2017, Pages 354-365
Professional and Academic Discourse:
an Interdisciplinary Perspective

\title{
Etumos Apistos, “Truly Doubtful”: Confounding Etyma in Scientific Nomenclature
}

\author{
Juan José Calvo \\ University of Valencia, Spain \\ juan.j.calvo@uv.es
}

\begin{abstract}
From the early $16^{\text {th }}$ century, Western European science systematically resorted to Latin and Greek, the two fundamental languages of its culture, to construct their terminology. The various Renaissance anatomical atlantes, the early $18^{\text {th }}$ century zoological and botanical taxonomies, the neo-Hellenisms of the late Ancient Régime chemists ... scientific nomenclature at large, systematically relied upon the premise of a shared cultural soil, regardless of nation of origin, mother tongue or field of knowledge. The neologism, the neo-Greek and/or neo-Latin construct shall, thus, be a common reference to all Western European languages and, consequently, the eventual linguistic mediator would not have to worry about transmission values except for lesser (spelling, phonetic, morphological, syntactical) adaptations and for fine, even subtle adjustments of the technical or the semi-technical terms. And yet, that confidence does not always turn out to be trustworthy and there are too many instances in which the source language etymon and the target language etymon do not match and the linguistic mediator, the translator or interpreter, is forced to rethink the inferred 'univocal' nature and the referential invariability of the terminology that is to be transferred.
\end{abstract}

\section{Premises}

When translating science and technology, we often trust on that univocal relationship that Ortega criticizes and are confident that, except for orthographic or ortho-phonetic adjustments, the triangulation of the 'transparent' terminology (especially in compounds and noun phrases) shall allow us to pursue our work within rather safe boundaries. The same way a vessel is doubly secured in place by means of anchors and moorings, that unswerving relationship rests upon two pillars of 'revealed truth': the reference to a canonical language and the presence of proper nouns (be they eponyms or derived eponyms), in the terminus technicus of the SL (henceforth L1) translation unit (henceforth transleme). 


\section{The Two Groups of 'Truth'}

\subsection{The Etymon of the Canonical Language}

\subsubsection{Goods Inherited: Latin and Greek}

When Ortega's dictum on scientific translation is published, three hundred years have elapsed since René Descartes decided to break with Latin and write science in the vulgar tongue. The Discours de la méthode pour bien conduire sa raison, et chercher la vérité dans les sciences was anonymously published in Leiden in June 1637 and José Ortega y Gasset wrote his essay between May and June 1937. Descartes' excuse was to put an end to medieval Scholasticism. The true reason was the attempt by France to substitute Classical cultural hegemony, which, in Western Europe, still was Latin. Eventually, despite Linnaeus groundbreaking and perennial taxonomies (Systema naturae 1735) and the works of other noteworthy individuals before and after him, the pincer of French cultural hybris and Protestant anti-Roman bigotry began to dissolve the lingua franca/koiné values of Latin from the middle of the $17^{\text {th }}$ century onwards. Today, while Latin and Greek are no longer compulsory secondary education subjects, understanding their affixes and their compound constituents remains indispensable for the better command of scientific terminology. Also, as already mentioned above, (neo)Classical etymology is felt to be a 'transparent' referential value and a lighthouse for translation. But this is not mathematically true and the resulting risks are the subject matter of the present paper.

\subsubsection{Goods Acquired: French and English}

In the wake of Latin and from the Baroque onwards, several languages assumed the role of communication languages ${ }^{1}$. French became the language of diplomacy and still is that of fashion, gastronomy and ballet. Since the Renaissance, Italian will be the language of fine arts and music. German will not only set down the linguistic milestones of the $19^{\text {th }}$ century, but will also be predominant in geology and chemistry, let alone in philosophy and psychoanalysis. After WWII, English and Russian turned hegemonic in their respective areas of influence until English becomes universal with the demise of the Cold War and the reunification of Europe.

In our present world, English functions as the cultural and commercial heir to Latin in the West, albeit without the support of Empire or Church. But it is in no way comparable to the values of the antedated, Greco-Latin etyma. The nomenclatures of the synchronic natural languages, stemming from more or less related parallel cultures, are more resistant to change and will not result in erroneous interpretations as may be the case with languages genetically related to each other. With a metaphor taken from Roman law, we could argue that the individual is not so prone to trans-form the goods acquired adventitiously and by contract, by cognate relationship, but will be rather feel inclined to do so with those agnate, received and inherited from one's father through the ius sanguinis, since the individual deems to have and hold the judicial plena propietas: the right of use (usus), enjoyment (fructus) and abuse (abusus) over those goods.

\subsection{The Etymon of the Proper Noun}

The second safety-lock of our terminological trust is the 'sacred' value of the proper noun: from the Modern Period onwards and for most of the Western World, a proper noun is considered untouchable: untranslatable, irreplaceable.

Now statistically, this is not true. When we analyse the lexical field of biology in our background corpus we have the following data: in botany, out of 574 geonymic eponyms 31 (5\%) are appropriated and 116 (20\%) appropriate the proper noun and/or triangulate the common noun by translation; and out

${ }^{1}$ Alcaraz (2000: 43) calls them niveladores 
of 111 anthroponymic eponyms 70 (63\%) are appropriated and 6 (5\%) appropriate the proper noun and/or triangulate the common noun by translation. In zoology, out of 189 geonymic eponyms 46 (24 $\%$ ) are appropriated and 84 (44\%) appropriate the proper noun and/or triangulate the common noun by translation; and out 55 anthroponymic eponyms 24 (42\%) are appropriated and 13 (22\%) appropriate the proper noun and/or triangulate the common noun by translation. This does not exclude the possibility of hybrid transfers, including appropriation and triangulation as well as substitution, be it cultural (what Vinay and Darbelnet dubbed adaptation) or not, nor does it rule out full or partial omissions due to ignorance of the referent which is needed for the triangulating translation procedure.

Within our corpus, eponymy and derived eponymy offer different translation options:

a) the incorporation of the eponym in the 'lay' level of the language, and not those of the 'semitechnical' calques or Greek-Latin 'technical' levels ${ }^{2}$

b) the choice among different culturally opposed options, with (anthroponymic) syntheses, additions or reductions

c) the 'denaturalization' or forsaking an eponym of the target language culture (N2)

d) the change of a third language culture (N3) anthroponym for one of a different N3

e) the exchange of geonym for anthroponym and viceversa.

\section{The Corpus}

The corpus belongs, first and foremost, to the health sciences and to physics, chemistry, botany and zoology, mineralogy and astronomy; to liberal and social sciences such as art, linguistics, psychology, theology, philosophy, history, geography, plus some other odd examples. We divide the terms into three diaphasic levels: 'lay' (e.g. Spanish hierro, Portuguese and Italian ferro, French fer, English iron, Danish jern, Swedish järn, German Eisen or Dutch ijzer), 'semi-technical' (typically, but not only, calques or adaptations which can be ortho-phonetic like Spanish cauterio, crisótilo, diafragma, hipocorístico or hipóstasis; phonetic like vagina; suprasegmental like Spanish cartílago and semantic (called in English loantranslations), like the Spanish Arabism tabique or German Scheidewand for Latin septum) and 'technical', (adoptions (borrowings), at least in spelling and de visu, like Spanish and English hepatitis or English phthisis, which has three valid phonetic realizations: ['Өarsis], ['taisis] and ['f $f$ aisis]). Our greater attention should be devoted to the 'lay' level and to the oral over the written medium. First, because linguistic and cultural substitutions are easier to detect and second because, with oral mediation (simultaneous or consecutive interpreting and chuchotage), the time pressure makes it more likely for linguistic interferences to occur.

Almost all the Spanish translations were taken from Beigbeder Atienza's two-volume bilingual dictionary. The medical ones come from Beatty et al (2004) bilingual Stedman and the monolingual Diccionario terminológico de ciencias médicas (DTCM) coordinated by Navarro Beltrán. Some examples have been drawn from Van Hoof and other scientific and technical translation references, apart from minute contrasts from Wikipedia.

${ }^{2}$ Alcaraz (200: 42 s) understands something else under 'semi-technical' and 'technical'. We have preferred to maintain this threefold division both for translation purposes and for the categorization of diaphasic changes within the linguistic contrast. 


\section{Categorization of Translation 'Risks'}

\subsection{Introduction}

As mentioned above, within the bilingual contrast the translator will have to face a whole range of potential 'risks' that might handicap his work, especially if, as usual, he is working under time pressure. Sometimes the range is narrowed, as when we contrast a Romance language with a Germanic language of solid scientific tradition like German itself. This language has been, since the early Middle Ages, notably resistant to the appropriation (adoption or borrowing and adaptation or calque) and has preferred, if at all, the recourse to semantic adaptation (loan translation), especially with semantically transparent compounds or derivations. In other cases, the risk lies in what we might dub 'spurious common denominator by induction' sci. lexical coincidence or near coincidence in various Western languages which will notoriously increase the possibility of an error. Mutatis mutandis, we could recall, with the non-marked and common core language, the bewilderment of a tourist in Iberia when confronted with Spanish cerveza or Portuguese cerveja, which bear no similarity with French, Italian, English, Dutch and German bière, birra, beer, bier or Bier (except for the Spanish birra, which is kurolectic, juvenile slang); while the Spanish waiter does not realize that his jamón like its French counterpart jambon (< jambe "leg") or even English and Dutch ham (both from Common Germanic * $\chi a m$ - "curved", cf. Spanish corva), are not only totally unrelated to German Schinken, Swedish skinka or Danish skinke (< Old High German scinco "thigh" < Indoeuropean *[s]keng- "curved")) ${ }^{3}$, but even to Portuguese presunto or Italian prosciutto (both from Latin per sunctus < per siccatus "very dry"). Within our corpus, the C1, the first cervical vertebra, will be atlas in Spanish. French, English and German, but Italian adapts it as atlante; and while the C2 will be axis in Spanish. French and English, Italian chooses the adaptation epistrofèo and German the transparent reference of the mother tongue: zweiter Halswirbel ("second neck vertebra"). Going down the spine to its caudal and distal end, Latin coccyx is adapted in French coccyx, English cóccix and Italian coccige, while Spanish prefers Greek coxis instead. In a German surgery, physician and patient will use German Steißbein for oral communication, but the written and formal term is os coccygis. This Germanic tradition can also be seen in English shoulder blade and German Schulterblatt, vs. the 'technical' Latinism scapula or the Italian adaptation scapula, again in contrast with the Greek adaptations in Spanish omoplato/omóplato (escápula being less usual) or French omoplate.

Let us now see the different options that present themselves to the linguistic mediator.

\subsection{The Translation Options}

\subsubsection{A Classical tongue: Latin or Greek}

Normally, a Romance target language (L2) will replace the original source language (L1) term with a Latinism, a Graecism or a hybrid of both. Thus, German Weltanschauung is appropriated in English, while Spanish prefers the Greek-Latin compound cosmovisión and Jacob Grimm's linguistic neologisms Ablaut and Umlaut (appropriated in English) are substituted by the neo-Greek constructs apofonía and metafonía in Spanish.

This option can be absolute, as with the German morphological adoptions (except, as always, for the obvious transliteration) of Greek Antibiotikum/Antibiotika vs. the English, Spanish/Portuguese, French and Italian adaptations antibiotics, antibióticos, antibiotiques and antibiotici. But the morphological appropriations can also be partial and depend on the diaphasic level, as with the English

\footnotetext{
${ }^{3}$ Drosdowski, Günther \& Grebe, Paul. 1963. Der Grosse Duden 7. Herkunftswörterbuch. Die Etymologie der deutschen Sprache. Mannheim Wien and Zürich: Bibliographisches Institut AG Duden Verlag.
} 
foreign plurals, i.a. dogmata and cherubim vs. dogmas and cherubs or indexes in library management and índices in mathematics or antennas in electronics vs. antennae in zoology.

\subsubsection{An Alternative Classical Tongue: either Latin or Greek,}

\subsection{The Absolute Alternative Option}

The absolute alternative option, - -i.e. the decision to choose the technical term in either Latin or Greek - can be seen in the Spanish, French, Portuguese and Italian adaptations peroné, pérone, perónio and peroneo (< Greek peróne "pin", "brooch") vs. the English adaptation fibula (< Latin fibula "pin", "brooch"); while, in Art, fibula is common to all and only suffers minor ortho-phonetic modifications.

3.2.1.1.2 The Alternative Option, according to the Field or Subfield of Specialized Knowledge

According to Fluck (1976: 92), Latin would predominate in anatomy and Greek in pathology within the field of medicine. Certain is that the 'technical' references to tumors make use of the Greek components -cele ("tumor", "hernia”, "tumefaction") or -oma ("tumor", tumefaction"). This dichotomy can also be seen in contrasts like vértebra, vertebra, vertèbre vs. spondilopathy, Spondylopathie, spondylopathie, espondilopatía or articulación, Artikulation, articulation, articolazione, articulação vs. artrosis, arthrosis, Arthrose, arthrose, artrosi and artrose, to mention just a few. But it is not consistent.

Something similar can happen with various false cognates: English conductor is Spanish conductor in physics, but revisor (de autobús) and orchestra director; relapse is relapso in theology but recidivo in pathology.

3.2.1.1.3 The Partial Alternative Option of a Hybrid, with one Etymon of the same Origin and the other one of the Second Classical language

We best see this specific option in a single but marked example: the English neo-Graecism logorrhea in contrast with the Spanish Graeco-Latin hybrids verborrea/verborragia with the same meaning.

3.2.1.1.4 The Absolute Alternative Option of a Linguistically Common Etymon (Latin or Greek) but Originating in a Different Lexeme

We can also observe this phenomenon in neo-Latin adaptations like Spanish and Portuguese cúbito, Italian cubito and French cubitus (all from Latin cubitus) vs. English and German ulna ( $<$ Latin ulna) or in the neo-Greek otorrinolaringólogo in Spanish or French oto(-)rhino(-)laryngologiste instead of the more adequate Italian otorinolaringoloiatra. It is well-known that, in chemistry, nitrogen (Greek "saltpeter producer") is azote (erroneously derived from Greek $\alpha \zeta \tilde{\omega} o \varsigma$ (azōos) "lifeless") in French (cf. Maillot 1997: 253). In mineralogy, the 'semi-technical' neologisms amianto in Spanish and asbestos in English can be told apart from Spanish asbesto and English amianthus, both in their diaphasic level and in the frequency of use. Finally, we can also call to mind the replacement of Medes by Persians, in Spanish Guerras médicas and French Guerres médiques vs. Persian Wars (o Graeco-Persian Wars) Perserkriege, Perzische Oorlogen, Perserkriegene and Guerre persiane in English, German, Dutch, Danish and Italian; or e.g. the Spanish-English contrast Guerras Púnicas and Carthaginian Wars (though Punic Wars is also possible).

\subsection{The Option of a Different Spelling}

Since it is generally unexpected, differences in spelling represent a major obstacle everywhere within our corpus, with a quid pro quo frequency that turns it practically into a minefield. We see it in English rubella and Spanish rubeola or in Maglemosian/Maglemosean (culture) and (cultura) 
maglemoisense ${ }^{4}$. Similarly, German Neoplasie, Spanish and Italian neoplasia or French néoplasie contrast with English neoplasm and Portuguese neoplasma. The English Hellenism syncope will be Spanish síncope in medicine, but síncopa in linguistics. Being Latin, incapable (like English and like French) of pronouncing the velar voiceless fricative corresponding to the Greek letter $\chi$, it was assimilated to the voiceless velar plosive $/ \mathrm{k} /$, 'reminding' the reader of the etymological friction by adding an $h$ to the $c$ in the digraph $c h$. In the transmission of the digraph to a nonRomance language like English ${ }^{5}$ and in examples containing the Greek prefix $\dot{\alpha} \rho \chi$-/ $\dot{\alpha} \rho \chi l^{-}$-, orthographic and phonetic adoption is invariably found: archaebacteria, archaeopteryx, archaic, archangel, archbishop, archdiocese, archdeacon, archaeology, archduke, archenteron, archesporium, archetype, archimandrite, archipelago, archiphoneme, archiplasma, architecture, archive, archmage, archpriest among many others. On the contrary, a direct heir to Latin like Spanish shows a wide range of ortho-phonetic varieties: arquebacteria, archaeopteryx, arcaico, arcángel, arzobispo, archidiócesis, arqueología, archiduque, arquénteron, arquesporio, arquetipo, archimandrita, archipiélago, arquiplasma, arquitectura, archifonema, archivo archimago and arcipreste, including paronymic synonyms like archidiácono and arcediano.

Spelling differences according to the national standard imply a further problem. Leaving wellknown ones like the-mme/-m (e.g. gramme-gram, programme-program), -or/-our (e.g. armour/armor) -re/-er (metre/meter) or -ce/-se (e.g. defence/defense, vice/vise), American English writes i.a. aluminum for British aluminium, mollusk for mollusc, pedology for paedology, diarrhea for diarrhoea, electron tube instead of electronic tube or carburetor and not carburetter; and these 'national' differences can be found in any technical or scientific field.

\subsection{The Option of a Different Affix or Bound Morpheme}

This feature is well marked in chemistry, scilicet in the different 'readings' of the formula $\mathrm{NaCl}$, where only German Natrium Chlorid and Dutch Natriumchloride duly reflect the binomial components; and where we have Spanish cloruro de sodio/sódico, Italian cloruro di sodio, French chlorure de sodium, Portuguese cloreto de sódio and English sodium chloride (cf. Maillot 1997: 252). On the contrary, the 'lay' and non-marked lexemes, like Spanish and Portuguese sal, Italian sale, French sel, English, Danish and Swedish salt, German Salz or Dutch zout do not invite confusion. Something similar occurs with Spanish permanganato de potasio which retains the $\mathrm{K}$ of the formula $\mathrm{KMnO}_{4}$, in German with Kaliumpermanganat, rejecting the etymologies that stem from their own culture. Let us bear in mind that Kalium, mediated by medieval Latin, comes from Arabic al qalya ("vegetable ash"), while neo-Latin potassium (as dubbed by Humprey Davy in 1807) comes from German Potasche ("pot ash").

\subsubsection{The Option of the Vulgar Tongue}

\subsubsection{The Absolute Option of a Vulgar Tongue}

A typically/topically Germanic option, we can observe this 'cultural' tendency in two examples of pathologies which have very similar spellings in English. In the first one, the isolated Italian adaptation morbillo (< Latin morbilius, cf. morbilli virus), stands alone versus the general tendency in favour of the vulgar tongue that we see in Spanish sarampión and Portuguese sarampo ${ }^{6}$, German Masern, Dutch mazelen, English measles, Danish maeslinger or Swedish mässling, (all from Common Germanic *mas"spot") or the separate and unrelated example of French rougeole etymologically hybrid of rubéole. The second one is German measles (rubella in the 'technical' diaphasic level after Henry Veale 1894). In German it is Röteln since the middle of the $18^{\text {th }}$ century and, in Spanish and Italian, rubeola; in

\footnotetext{
${ }^{4}$ For more examples of spelling changes, cf. Van Hoof (1999: 203-205).

${ }^{5}$ Though not in German, for instance.

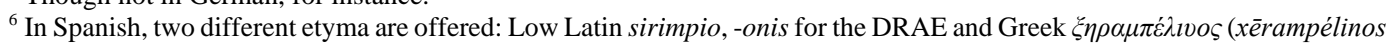
"of the colour of a dry vine leaf") for the DTCM.
} 
Portuguese rubéola and rubéole in French, ultimately all from Latin rubeus "reddish". This is more than common in anatomy. We find radius in English and French, radio in Spanish and Italian, or rádio in Portuguese vs. the native German option Speiche. We also see it in the French, Italian, Portuguese Latin adaptations sternum, sterno, esterno or in the Spanish esternón adaptation of Greek $\sigma \tau \varepsilon \dot{\varepsilon} \rho v o v$ ("breast"), in contrast with the Germanic compounding of English and German breastbone and Brustbein. The same is true of chemistry. The French neo-Hellenisms oxigène and hydrogène (de Morveau and Lavoisier 1787), indicate the capacity of these gases to produce acid and water. German makes use of its habitual semantic adaptation and gives Sauerstoff and Wasserstoff; similarly nitrogen as Stickstoff ("matter that smothers"), although, here, German does not adapt semantically the Greek neologism but rather reinterprets the etymological values ("lifeless") of French azote. Outside the natural sciences, we can observe this e.g. in prehistory, as in the 'technical' homo rhodesiensis, which can be replaced in English by the 'lay' Rhodesian man; or, in geography, in the general Germanic (except English) substitution of Latin mare balticum by "East(ern) Sea”: Ostsee in German, Oostzee in Dutch, Oossee in Afrikaans, Østersøen in Danish, Østersjøen in Norwegian bokmål, Östersjön in Swedish and Eystrasalt in Icelandic and Feroese.

3.2.2.2 The Absolute Option of a Vulgar Tongue that Coincides with or Translates the Original

The best example for the preference of a vulgar tongue which is deemed a correct translation option may be Sigmund Freud's Das Ich und das Es (1923) where Es, Ich and Über-Ich were arbitrarily given as id and ego, superego in James Strachey's canonical version (1953-1966). On the contrary, Spanish has Ello, Yo and Super-yo, since the Luis López-Ballesteros y de Torres (1924) translation, although the Latin names are also used.

\subsubsection{The Option of a Vulgar Tongue in only one of the Components}

Examples would be French synthèse de l'eau vs. Spanish hidrosíntesis or German hybrid Muskelatrophie vs. the purely neo-Greek compounds in Spanish, French, English, Italian and Portuguese amiotrofia, amyotrophie, amyotrophy and amiotrofia. We can also observe this in the 'semitechnical' German Weißer Jura or Weißjura and its English adaptation White Jurassic or White Jura, which will normally be matched to jurásico superior in Spanish, although the historical overlapping is not precise.

\subsubsection{The Option of a Different Vulgar Tongue}

In chemistry, $\mathrm{W}$ has two adapted lexemes in Spanish: the originally Swedish compound tungsten(o) (Swedish "heavy stone") and the originally German compound wolfram(io) (German "wolf cream"). Spanish, but also Portuguese can choose. German (and curiously enough Swedish itself) only accepts Wolfram. English French and Italian prefer the adaptations tungsten or tungstène, while acknowledging that $\mathrm{W}$ stands for Wolfram. The IUPAC has not been able to reach a consensus.

\subsubsection{The Option of a Vulgar Tongue Depending on the Field of Knowledge}

English pectoral will be Spanish pectoral in anatomy and in liturgy; but, in pharmacology, Spanish

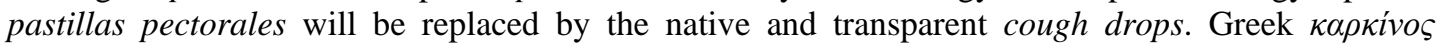
(carcínos) is the 'lay' name of the mollusc we call crab and Hippocrates used it as a formal metaphor for some cancerous tumours. In Greek mythology, Karkinos, the giant crab that Hera sent to assist the Hydra against Herakles in the Lerna lagoon, was transmuted by the goddess into a constellation. In Roman culture, Aulus Cornelius Celsus, the scholarly contemporary of Emperor Augustus, triangulated the mollusc and all the other referents into cancer. In Spanish, this Latin lexeme has become a tetrad: cáncer, cangrejo, chancro and cancro. The spelling adaptation cáncer is valid for oncology, astronomy and astrology; the ortho-phonetic adaptations chancro and cancro for general pathology and botany 
respectively; cangrejo for zoology and hoplology ${ }^{7}$ as well as a formal metaphor, in sailing ships. To choose but one other of the languages contrasted in the present paper, German reduces the four 'teeth' of Spanish to two. Latin cancer is triangulated as Krebs for oncology, astrononomy, astrology, zoology, botany, hoplology and musicology ${ }^{8}$; it is also found in the mercantile oral half-slang as a formal metaphor to refer to books returned unsold. The second 'tooth' is the ortho-phonetic adaptation Schanker, correlative to English canker, Spanish chancro, French chancre and Italian and Portuguese cancro. Greek carcinos will be retained for oncology, like the redundant neo-Hellenism carcinoma in English, Spanish, Italian and Portuguese, French carcinome or German Karzinom, together with other odd fifteen terms.

\subsubsection{The Option of an Alternative Source Language, Mediated by a Classical Language or not}

Just a couple of instances. Firstly, the Arabic article, fused by metanalysis, in Spanish azufre or the Gothic swibls that resulted in German Schwefel, Swedish swafel and Dutch zwavel, instead of accepting Latin sulfur, which is masked as Greek in sulphur in British though not in American English. The second example is taken from botany: English larch comes from German Lärche and, ultimately, from Latin larix and could be 'genetically confused' with the Spanish Arabism alerce, whose similarity with the Latin form is, for Corominas (1955-1957: 108), no more than accidental isomorphism.

\subsubsection{The Option of a Term that Includes an Eponym or a Derived Eponym in one} or both Languages in Contrast

\subsubsection{Geonyms}

The specific option by means of which a specific language may opt for a genonymic reference instead of the 'common' Graeco-Latin term can be exemplified with the German compound Nilpferd

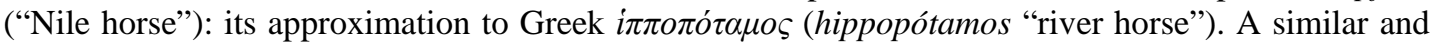
rather idiosyncratic example can be observed in the contrast between Spanish ácido pícrico and the English derived geonym lyddite (from the Kentish town of Lydd), documented since 1888.

\subsection{Controversial Geonyms}

In European geography, one of the oldest examples is probably German, English, Dutch, Danish, Norwegian (both bokmål and nynorsk) and Swedish Genfer See, Lake Geneva, Meer van Genève, Genevesøen, Genfersjøen and Genèvesjön to refer to what Julius Caesar, using a pleonastic and redundant metanalysis, named lacus lemanus (i.e. "lake" in Latin + the adaptation of the word for "lake"

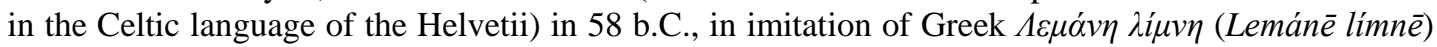

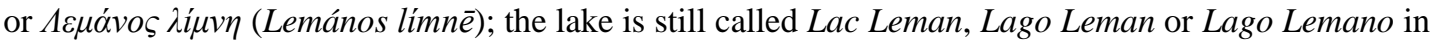
French, Spanish, Italian and Portuguese. It is only logical that controversial geonyms crop up in shared and/or bordering territories (The English Channel/La Manche, Strait of Dover/Pas de Calais, Danzig/Gdansk, Falklands/Malvinas, Sajalín/Karafuto), also when referring to historical events like battles that are part of two or more historical traditions (La Moskova/Borodino, Blenheim/(Zweite) Schlacht bei Höchstädt). These eponyms can be easily guessed depending on which 'side' the target language culture, the N2 lies. Even in cases where this is not necessarily given, the N2 will respond to one historiographical tradition or another, and the resulting eponym will also be easily perceived: the

\footnotetext{
${ }^{7}$ A neologism taken from Greek ö $\pi \lambda$ ov (hóplon) “weapon”. Within this lect or register, Krebs and cangrejo refer to two parts of the late medieval and Renaissance body armour: the breastplate in German and the articulated protections for elbow pits and knee hams in Spanish.

${ }^{8}$ The German musical term Krebskanon (also known as retrograder Kanon), typical of the Baroque and of Johann Sebastian Bach, the Latin canon cancrizans, becomes crab canon in English, canon à cancrizans in French, canone cancrizzante or canone retrogrado in Italian and canon cancrizante or canon retrógrado in Spanish; but in none of them, except in German, is the metaphor transparent.
} 
Deutscher Krieg will be Guerre austro-prussiene in French, Austro-Prussian War in English, Guerra austro-prusiana in Spanish and Guerra austro-prussiana in Italian; but not in Dutch, which will typically follow the German nomenclature and give Duitse Orlog. On the other side of the world, the naval Battle of (the Strait of) Tsushima is that of the Sea of Japan for the Japanese; but Europe knew of it through the Russian Empire and adapted its geonym: Цусимское сражение (Tsusimskoye srazheniye). Even word-order can be a matter of dispute and result in transfer problems: German Deutsch-französicher Krieg and French Guerre franco-prusienne neither say the same thing, nor foreground the same countries. True is that, as we shall see with the anthroponymic controversies, a synthesis can eventually be agreed upon: the battle of Königgrätz is that of Sadowa, for the French and English historiography, and Spanish can compromise by calling it La batallla de Sadowa-Königgrätz. And yet, not even the fact of having being allies helps, as shown by the examples Battle of Corunna (city)/Batalla de Elviña (village), Battle of Barrosa (beach)/Batalla de Chiclana (town), Battle of Salamanca (city)/Batalla de los Arapiles (mountains), all of them corresponding to the Peninsular War/Guerra de Independencia. And to the translator's ultimate despair, not even sharing language and country assures a common eponymy, since we have alternative names for the American Civil War battles, from the very first shot: Bull Run for the Union and Manassas (Junction) for the Confederates.

\subsubsection{Anthroponyms}

\subsubsection{1 'Lay’ Anthroponyms}

Within the 'lay' level in both languages, in order to give English Jovian planet Spanish planeta gaseoso omits the anthroponymic reference and translates the common noun. With one degree difference in the diaphasic scale, the 'lay' level is found in American English Gehrig's disease for what the Spanish 'semi-technical' level calls esclerosis lateral amiotrófica. The difference of two degrees in the diaphasic scale can be seen in the 'lay' level Rhodes grass vs. the 'technical' chloris gayana in Spanish. Chemistry examples include Condy's crystals vs. the 'semi-technical' permanganato de potasio (although cristales de Condy also exists in Spanish). We have derived eponyms in the Spanish neo-Latin 'technical' adoption salicorna (< Latin salis "salt" + cornu "horn") vs. the English agnominal (respicial and sacral) derived eponym, the 'opaque' samphire ( $<$ Saint Pierre) ${ }^{9}$. And let us finally refer to the common hereditary culture with the 'semi-technical' adaptation óxido cuproso vs. the 'lay' level crocus of Venus or to Anglo-Saxon culture with the Latin adaptation salvelina in Spanish vs. the Dickensian Dolly Varden trout.

\subsection{Alternative Anthroponyms}

There are several possibilities, distributed into two groups or sections. In the first section, the change implies choosing an anthroponym belonging to the same N1. As a first subordinate option the L2 adds another N1 anthroponym to the one already given, as Penrose diagram and diagrama de PenroseCarter in physics. The second one does the opposite, like Calvin-Benson-Bassham cycle and ciclo de Calvin (Benson) in botany. The third one chooses between two anthroponyms with the same referent. In electricity, the Kelvin double bridge is puente doble de Thomson in Spanish and both anthroponyms refer to the same person, since William Thomson became Lord Kelvin in 1892 (example apud Maillot 1997: 211). Within the second section, the change takes place by substituting an N3 anthroponym present in the TL1 by an anthroponym stemming from a different N3, as with the cognominal frangipani (arguably derived from the Frangipani/Frangipane of the Italian nobility) by the nominal plumeria (from the French Charles Plumier) in botany.

\footnotetext{
${ }^{9}$ The taxonomic explanation is as follows: 'agnominal' (< Latin agnomen) because it is a personal and not a hereditary byname, 'respicial' ( $<$ Latin respicere "to respect") because it is a title of respect and 'sacral' because it refers to a saint. It is etymologically ‘opaque’ like galoshes (< Late Latin gallica (solea) “Gallic shoes”), not ‘translucid’ like cerium (< goddess Ceres) nor 'transparent' like canary, that obviously relates to the Canary Islands (for the terminological analyses, vid. Calvo 2014 and 2015).
} 


\subsection{Controversial, Culturally Disputed Anthroponyms}

As with the geonyms, we can recall some of the anthroponymic culturally-bound controversies in sciences. Provided the L2 does not belong to one of the two cultures in dispute ${ }^{10}$, there are two options:

a) to choose one of both, as with English franklin vs. French statcoulomb and Spanish franklin or English Boyle's law vs. French loi de Mariotte and Spanish ley de Mariotte

b) to synthesize them, like English Pott's fracture and French fracture de Dupuytren, but fractura de Dupuytren o de Pott in Spanish or Graves’ disease in English, Basedowsche Krankheit in German and enfermedad de Graves-Basedow in Spanish.

\subsection{Tabooed, Culturally Rejected Anthroponyms}

We can also find examples of anthroponyms that are rejected by the N2, due to prestige motivations or not. As an instance of the first case, we have the disability which was baptised by Pierre Prévost, the Swiss philosopher and physician, as daltonisme in reference to the $18^{\text {th }}$ century English chemist and physicist John Dalton who had both suffered and diagnosed it. English prefers to call it colour blindness, rejecting that association as offensive. As an instance of the second case, the rays that Wilhelm Roentgen called $X$-Strahlen (1895) because he did not know their identity, were nominally rebaptised (Röntgenbild, Röntgentherapie, etc.) in German to honour his memory, but retain the original nomenclature ( $X$-rays, rayos $X$, and so on), in many European languages.

\subsection{Denaturalised Anthroponyms}

While it remains a rather uncommon occurrence within our catalogue of options, it can well happen that an anthroponym of the N2 culture is forsaken by that very culture in favour of an N3 one or even of a perfectly non-eponymous term. Thus, in the Spanish to English contrast, Ulloa's ring vs. halo de Bouger in the first case and Malaspina glacier vs. glaciar somontano in the second one

\subsubsection{Criss-cross Eponymy: Geonyms for Anthroponyms or Viceversa}

Less commonly, one type of eponym can be substituted by another one, like the English geonym Invernesss cape and the Spanish adapted nominal anthroponym macfarlán. This is even possible when it 'affects' an N2 referent, as seen in the aeronautical geonym Cuban eight and the Spanish nominal anthroponym Immelmann doble. And finally, to bring our analysis to the close, we can observe this phenomenon in a variant denomination of the already-mentioned nominal anthroponym Ulloa's ring/circle and the Spanish geonym espectro (de) Brocken, most probably through French espectre (de/du) Brocken and ultimately from German Brockengespenst.

\section{Conclusions}

We have seen that the translation options can be divided into two large groupings: those that fall back upon the Graeco-Latin etymology and those that opt for the vulgar, be it their own native language or any non-Classical language. Anthroponyms are considered a separate category. From the point of view of frequency, chances are that the linguistic mediator will come across the 'pure' varieties: either Latin/Greek or native tongue instead. Resorting to the native tongue should not worry him if the translation is e.g. from/to German, since he knows that, within the 'lay' level, German will make use of the native vocabulary or of semantic adaptations. As for the 'technical' level, at least in medicine and in some natural sciences, German will certainly rely on the neo-Greek and/or neo-Latin nomenclature.

\footnotetext{
${ }^{10}$ Examples of culturally controversial eponyms abound in chemistry and the IUPAC's terminological wavering has been of little help, e.g. the derived nominal anthroponyms karchatovium (USSR) vs. rutherfordium (USA) or nielsbohrium and hahnium versus the derived toponym dubnium.
} 
The most important problem in the first grouping is that of adoption vs. adaptation, above all the morphological adaptation possibilities (e.g. plurals) in languages like German and English. But the choice of one or the other Classical language also represents a handicap, since it often depends on the (sub-)field of specialised knowledge and the differing orthographic and transliteration conventions can make the translator's work more bewildering.

Within the grouping of the vulgar tongues —apart from what already has been said about German, the 'lay' level of language and the oral medium of communication: and also independently of the language in question, but bearing in mind the options offered by the oral exchange of information among specialists - the statistically greater risks are the options that depend on the (sub-)specialised field of knowledge.

Eponymy, not only that of natural sciences and of the technical jargons, but also those that are found in human and social sciences like geography and history represent a real bait because of the 'real-estate' values inherent to the proper nouns and the - perhaps obvious - inertia to use the same proper nouns found in his own culture. For, indeed, culture, as well as historiographical tradition or political controversy, can seriously interfere with language transfer, above all if the proper noun belongs 'naturally' to a given language/culture and that language/culture, against all odds and forecasts, ignores or rejects it... the intermediary may not be able to react in time.

\section{References}

Alcaraz Varó, E. (2000). El inglés profesional y académico. Madrid: Alianza EditorialBeatty, W. K. et al. (2004). Stedman bilingüe. Diccionario de ciencias médicas. Inglés-español Español-Inglés. (1 ${ }^{\mathrm{a}}$ edición, $2^{\mathrm{a}}$ reimpresión) Buenos Aires - Bogotá - Caracas - Madrid - México- São Paulo: Editorial médica panamericana.Beigbeder Atienza, F. [1988] $1997^{2}$ (inglés-español) and [1987] 2002² . (españolinglés). Diccionario politécnico de las lenguas española e inglesa. 2 volumes. Madrid: Ediciones Díaz de Santos.

Calvo García de Leonardo, J.J. (2014) “¿Canal anglais?, ¿Spanish omelette?, ¿Pasta italiana e Italian pasta? La geografía física y humana patente como escolio o escollo en traducción”, in Vargas Sierra, Ch. (ed.). TIC, trabajo colaborativo e interacción en Terminología y Traducción. Granada: Editorial Comares (Colección Interlingua 132): 317-330.

(2015). “¿DOC? La toponimia y la deonimia francesas, en la lengua y en el lenguaje, para el Hexágono y para los países limítrofes”, in Colón, G., Kremer, D. \& Casanova, E. (eds.). Toponímia Romànica. (Quaderns de Filologia. Estudis Lingüístics XX). Valencia: Universitat de València. Facultat de Filologia, Traducció i Comunicació: 313-336.

Corominas Vigneaux, J. (1955-1957). Diccionario crítico-etimológico de la lengua castellana. 4 volumes. Madrid: Gredos.

Diccionario de la lengua española. (DRAE) $\left(2014^{23}\right)$. (Edición del tricentenario. $1^{\text {a }}$ tirada, octubre de 2014). Madrid: Real Academia Española.

Drosdowski, G. \& Grebe, P. (1963). Der Grosse Duden 7. Herkunftswörterbuch. Die Etymologie der deutschen Sprache. Mannheim Wien \& Zürich: Bibliographisches Institut AG Duden Verlag.

Fluck, H-R. (1976). Fachsprachen. Einführung und Bibliographie. München: Francke Verlag GmbH.

Maillot, J. (1997). La traducción científica y técnica. Madrid: Gredos.

Navarro Beltrán, E. (ed.). (1992 ${ }^{13}$ ) Diccionario terminológico de ciencias médicas (DCTM). Barcelona: Elsevier Masson (Elsevier España S.L.).

Ortega y Gasset, J. (19615) [1937]. "Miseria y esplendor de la traducción”, in Obras completas, tomo V (1933-1941). Madrid (Revista de Occidente): 433-450. 
Oxford-Duden pictorial English and Spanish dictionary, The. 1995² [1979]. Oxford: Clarendon Press.

Oxford English dictionary. (1971). The compact edition of the complete text reproduced micrographically. 2 vol. (1984, $23^{\text {rd }}$ printing). Oxford: University Press. Complete text reproduced micrographically. Vol. 3 (1987). A supplement to The Oxford English Dictionary Volumes I-IV. Oxford: At the Clarendon Press.

Van Hoof, H. (1999). Manual práctico de traducción médica. Granada. Comares. 